\title{
Comparison of Perceptions of Barriers to Innovation Projects in the Companies in Serbia
}

\author{
Željko Saric \\ Educons University \\ Faculty of Project and Innovation \\ Management \\ Belgrade, Serbia \\ zeljkosaric33@gmail.com
}

\author{
Milan Bubulj \\ University Union "Nikola Tesla" \\ Faculty of management \\ Sremski Karlovci, Serbia \\ bubulj@famns.edu.rs
}

\author{
Ljjiljana Miletić \\ Educons University \\ Faculty of Project and Innovation \\ Management \\ Belgrade, Serbia \\ ljiljana.miletic@pmc.edu.rs ORCID iD: \\ http://orcid.org/0000-0003-3270-1891 \\ Jelena Matijaševic \\ University Business Academy, \\ Faculty of Law for Commerce and Judiciary, \\ Novi Sad, Serbia \\ jela_sup@gmail.com
}

\author{
Dragan Janjušić \\ University Union "Nikola Tesla" \\ Faculty of Management, \\ Sremski Karlovci, Serbia \\ dragan.janjusic@gmail.com
}

\begin{abstract}
Investigation was conducted with the aim to get insight into the perception of different barriers for implementation of innovation projects by the employees in the companies in Serbia in dependence of employees' educational level, their perception of companies' innovativeness and the ownership structure of the company. Questionnaire-based research of perception of risk, finance, employees, management, social environment and information related barriers was carried out in the companies with different ownership structure: public enterprises, subsidiaries of multinational companies and companies owned by domestic entrepreneurs. In addition to the company's ownership, respondent's education level and perception of company's innovativeness were used as independent variables. The hypothesis that the perception of the barriers to the implementation of innovative projects in companies in Serbia by employees depends on the level of their education was not supported while the other two hypotheses stating that perception of the barriers to innovation projects depends on employee's perception of company's innovativeness and the ownership of the company were both supported. High level of perception of barriers in Serbia imposes the limitations to the implementation of innovation projects in Serbia, and thus case-specific activities aimed at overcoming of barriers to innovation projects should be planned and implemented.
\end{abstract}

Keywords - innovation projects, barriers, employees, innovativeness, company ownership

\section{INTRODUCTION}

In the processes of economic globalization and digitalization, knowledge becomes the key factor for positioning and profitability of the companies. The innovating capacity represents the precondition for its survival under the conditions of harsh market competition. Innovation is represented by each system of organized and appropriate activities aimed at the creation of new or improved products, processes, organizational structures and management practices. Drucker [1] points out that the innovative activities provide new capacities to the resources aimed at creation of new value that represent specific tool for achievement of organizational changes to the entrepreneurs

The results of an innovative project can be the creation of new, improved products, technologies, processes, services and management structures. In this sense, creativity and innovativeness are two closely linked processes. Creativity leads to the generation of new ideas and innovativeness is a process following idea generation which transforms the idea into practical solutions. Mumford and Gustafson [2] point out that in the times of permanent and dynamic changes on the global market, successful entrepreneurs must-have capabilities for creativity and innovativeness that will support permanent improvements necessary for achievement and preservation of competitive advantages for the company.

Innovation is defined as the successful implementation of creative ideas within an organization [3, 4]. Creativity can generate new ideas, new approaches or solution that will not necessarily be transformed into innovative activities/projects. Due to diverse internal and external barriers, innovative processes are often terminated. Through removal of barriers for implementation of innovation projects, the realization of new/improved products on the market and advancement of organizational processes and management structures convenient conditions are created under which the value of existing resources is increased and competitiveness of the company is empowered. The influence of diverse barriers on implementation of innovation projects has been widely studied $[5,6,7,8,9,10]$ under different socio-economic contexts. Differences in obtained results point out clearly that structure of barriers for innovation projects depend highly on socio-economic and cultural environment in which the company operates. 
The socio-economic context of Serbia is quite specific. It was created through complex interaction of long-lasting period of specific form of selfmanagement socialism until the nineties [11] followed by the period of war and economic sanctions and long-lasting transition towards open market economy characterized with slow and partly unsuccessful privatization of the companies [12] and postponed entrance of multinational companies into Serbian economy [13, 14]. Due to the specificities of development path of Serbian society the process of innovating in the companies in Serbia should have also taken on specific features. Investigations related to the barriers for innovation processes in the companies operating in Serbia are scarce and related primarily to the management perceptions of barriers for innovation [15].

\section{LITERATURE REVIEW}

\section{A Definition and classification of innovations}

In the innovation-related literature, there is a number of definitions and classifications of innovations, with a lot of similarities, but also with a number of differences. The term "innovation" etymologically comes from the Latin word innovare which means to do something new [16]. Innovation essentially represents the advancement of technology, process, new product or service. Innovation is a result of the application of own or other research results, ideas, inventions, knowledge, concepts or methods, which are put on the market with the appropriate value [17]. According to the OECD [18], innovation is the implementation of a new or significantly improved product (good or service), or process, a new marketing method, or a new organisational method in business practices, workplace organisation or external relations".

In terms of OECD classification innovations are classified to the product, process, market and organisational innovations. Innovations are also classified as radical (completely new) and incremental (evolutionary) ones.

Today innovations are considered from the wider business aspects. One of the contemporary classifications of innovation is provided by Schumpeter with five types of innovations: (1) introduction of a new product; (2) Introduction of new production method; (3) Opening of new market; (4) Utilization of new raw material or by-product; (5) Industry reorganization [19].

Observing innovations in a wider context of business [17] gives the following classification of innovations: (1) Innovation of a product that is new at the market; (2) Innovation of a product that is new for the company; (3) innovation of processes; (4) Management related innovations; (5) Marketing related innovations; (6) Learning-related innovations and (7) Innovations related to finance.

\section{B Internal and External Support for Innovation projects}

The basic role of innovation processes and projects is to generate certain organizational, technological and management changes that will, in the future, with a greater degree of efficiency, costeffectiveness and profitability, affect the overall growth and development of the company and the achievement and maintenance of the competitive advantage of the company on the market [20]. In order to attain this organization has to be innovative.

The innovation process is realized through three main transformation phases [21]: invention (patent), innovation (market evaluation of the invention) and diffusion (application of the innovation). Having in mind that new solutions for products and processes and new technological solutions represent important intellectual asset of each company, permanent support from the top management to the employees is needed in order to motivate them to demonstrate their creative potentials as well as in order to generate convenient climate for realization of innovative projects [16]. Cummings and O'Connell [22] point out the importance of leadership among the most important factors affecting innovation. Leadership influences the organizational preconditions through modelling of strategies, cultures, structures, climate and reward system [23, 24], but it also affects the employees' behaviour, their creativity [25], as well as their motivation [26] for innovative work. In this way, a supportive environment supporting creativeness [3, 27] and organization climate and policy for the realization of innovative processes [28] and support to the increase of employees' competences for innovative work [29] is created.

Innovative projects demonstrate diverse effects on the functioning and development of the organization. Through implementation of innovative projects production costs levels, quality level of the products, effectiveness and efficiency of processes might be affected and consequently increase the competitiveness of the company. Oppositely, lack of timely support to the implementation of innovative projects from the top management or investment in inappropriate projects might jeopardize the competitive position of the company and lead to the failure of the company. For achievement of the leading position of the company, the leaders and the managers have to teach the employees how to develop permanently their competences and how to use creative demands from their clients [30].

Creation of a suitable strategic framework and system conditions for the implementation of innovative ventures also implies that company leaders and managers respect the requirements of international quality management standards and take into account the potential risks and opportunities of their business. Experience from practice points out that only a small number of innovative ideas turns into innovations through innovative projects and gain commercial dimension in the market. For this reason, it is important for the leaders to be aware of potential 
barriers to innovation processes in their company. Among the reasons that crucially influence the fact that many good ideas generated by employees in the company do not turn into innovation projects are certainly the lack of support from the top management, the lack of sufficient knowledge and competencies and the lack of financial resources. Barriers for implementation of innovative projects were in the focus of numerous researchers $[31,5,8$, 32]. Based on the conducted research, it has been confirmed that barriers to the implementation of innovation projects vary in dependence on the company's profile [7]. The barriers to the implementation of innovative projects can be attributed to different causes and sources: innovation risks [6], financial aspects of implementing innovation projects, employee and management attitudes [33, 34] constraints imposed by the environment in which the company operates [35], availability of information [10] and others. Finding out of effective ways to manage barriers to the implementation of innovative projects is a prerequisite for successful business operations [9].

The sources and the drivers of the barriers for innovation projects implementation vary in dependence on the macro (state and its national culture) and the micro (company) environment in which the company and its employees are located. Surveys of perception of barriers for implementation of innovation projects have been conducted in various socio-economic and cultural environments $[8,33,35$, 5]. In Serbia, in [15] Lekovic conducted the investigation of the perception of barriers for innovation among managers and concluded that there are differences in perception of barriers in dependence of age (different perception of cooperation with competition) and sex (different perception of funding, workforce and innovation abilities) of the managers.

\section{EMPIRICAL RESEARCH}

\section{A Definition and classification of innovations}

The goal of the empirical research was to get the insight into the perception of barriers for initiating and implementing of innovative projects by the employees in the companies in Serbia, in dependence on the employee's level of education, the perception of the innovativeness of the company by the employee and the ownership structure of the company.

\section{B Research hypothesis}

The first starting assumption was that higher levels of education provide the information that contributes to a better understanding of the barriers to the implementation of innovation projects and, accordingly, the barriers will be perceived as higher by the respondents with the university degree in comparison to the respondents with high school education. In this sense, the following hypotheses were defined:
Ho1 Perception of the barriers to the implementation of innovative projects in the companies in Serbia by the employees depends on their education level

$\boldsymbol{H}_{01-1}$ Employees with high school education perceive barriers to innovation at a lower level than the employees with university education

The second assumption was that the perceived innovativeness of the company by the employee influences the perception of the barriers for the implementation of innovative projects in the company. This assumption was tested through the following hypotheses:

$\mathrm{H}_{02}$ Perception of the barriers to the implementation of innovative projects in companies in Serbia by the employees depends on employee's perception of their company innovativeness

Ho2-2 Employees who perceive their company as non-innovative perceive the barriers to the implementation of innovative projects at a higher level in comparison to employees who perceive the company as innovative

The third assumption was that the perception of the barriers for the implementation of innovation projects differs in dependence of companies' ownership structure. This assumption is analyzed through the following hypotheses:

$\mathrm{H}_{03}$ Perception of the barriers to the implementation of innovative projects in companies in Serbia by employees depends on the ownership structure of the company

Ho3-1 Employees in public companies in Serbia have the lowest perceptions of barriers to the implementation of innovative projects

Ho3-2 Employees in multinational companies' subsidiaries in Serbia have the highest perception of barriers for the implementation of innovative projects

\section{Research methods, techniques and instruments}

The research was carried out using the questionnaire (Table 1), which was designed to measure the perception of different barriers to the initiation and implementation of innovation projects.

The research was carried out in the companies with different ownership structure: in public enterprises (35\% of respondents) in subsidiaries of multinational companies (37\% of respondents) and in companies owned by Serbian entrepreneurs (28\% of respondents). In each company involved in the survey, the management representative was selected who distributed questionnaires so that representatives of different educational profiles and employees at different levels of management were equally represented. A total of 366 respondents from 15 companies participated in the survey. The research was conducted in the period 2015-2017 in companies located in major cities of the Republic of Serbia: Belgrade, Novi Sad, Niš, Kragujevac, Subotica, Novi 
Pazar and Zrenjanin. Out of the total number of respondents, $56 \%$ were women, and $44 \%$ were men. By age categories, $42 \%$ were younger respondents (up to 35 years), $30 \%$ were middle-aged (35-45 years), and $28 \%$ were an older generation (over 45 years). In the research, $43 \%$ respondents with high school education and $57 \%$ of respondents with university education participated. In the questionnaire, the respondents evaluated the degree of impact of barriers to the initiation and implantation of innovation projects in their companies using the Likert scale (1$7)$. The questions in the questionnaire were designed to enable evaluation of the barriers to innovative projects that can be attributed to: (1) the risks associated with innovation; (2) the financial aspects of innovation projects; (3) the behavior of employees; (4) the actions of company management; (5) the environmental factors and (6) the availability of information.

TABLE I. QUESTIONNAIRE FOR QUANTITATIVE SURVEY OF PERCEPTION OF BARRIERS TO INNOVATIONS

\begin{tabular}{|c|c|c|c|}
\hline 1. Respondent: & Under 35 & $35-45$ & Over 45 \\
\hline Age & Female & \multicolumn{2}{|c|}{ Male } \\
\hline \multicolumn{2}{|c|}{ Education } & High school & \multicolumn{2}{|c|}{ University } \\
\hline $\begin{array}{c}\text { 2. Did your company implement any } \\
\text { innovation during the last two years? }\end{array}$ & yes & no \\
\hline
\end{tabular}

3. Rate the importance of listed barriers for innovation in your company:

RISK RELATED BARRIERS

\begin{tabular}{|l|l|l|l|l|l|l|l|}
\hline \multicolumn{1}{|c|}{ Increased risk } & 1 & 2 & 3 & 4 & 5 & 6 & 7 \\
\hline $\begin{array}{l}\text { Turbulent economic } \\
\text { situation }\end{array}$ & 1 & 2 & 3 & 4 & 5 & 6 & 7 \\
\hline
\end{tabular}

COSTS RELATED BARRIERS

\begin{tabular}{|l|l|l|l|l|l|l|l|}
\hline \multicolumn{1}{|c|}{ High costs } & 1 & 2 & 3 & 4 & 5 & 6 & 7 \\
\hline $\begin{array}{l}\text { Difficulties in management } \\
\text { of innovation costs }\end{array}$ & 1 & 2 & 3 & 4 & 5 & 6 & 7 \\
\hline $\begin{array}{l}\text { Difficulties to access } \\
\text { innovation funding sources }\end{array}$ & 1 & 2 & 3 & 4 & 5 & 6 & 7 \\
\hline
\end{tabular}

\begin{tabular}{l|l|l|l|l|l|l|l|l}
$\begin{array}{l}\text { Difficulties to access } \\
\text { innovation funding sources }\end{array}$ & 1 & 2 & 3 & 4 & 5 & 6 & 7
\end{tabular}

EMPLOYEES RELATED BARRIERS

\begin{tabular}{|l|l|l|l|l|l|l|l|l} 
Resistance of employees to & 1 & 2 & 3 & 4 & 5 & 6 & 7
\end{tabular}

\begin{tabular}{l|l|l|l|l|l|l|l} 
changes & 1 & 2 & 3 & 4 & 5 & 6 & 7 \\
\hline
\end{tabular}

\begin{tabular}{l|l|l|l|l|l|l|l} 
Lack of qualified workforce & 1 & 2 & 3 & 4 & 5 & 6 & 7 \\
\hline Lack of internal trainings & 1 & 2 & 3 & 4 & 5 & 6 & 7
\end{tabular}

for employees

\begin{tabular}{|l|l|l|l|l|l|l|l|}
$\begin{array}{l}\text { Problem of retention of } \\
\text { qualified workforce }\end{array}$ & 1 & 2 & 3 & 4 & 5 & 6 & 7 \\
\hline
\end{tabular}

MANAGEMENT RELATED BARRIERS

\begin{tabular}{|l|l|l|l|l|l|l|l|}
\hline Lack of systemic activities in & 1 & 2 & 3 & 4 & 5 & 6 & 7
\end{tabular}

\begin{tabular}{l|l|l|l|l|l|l|l|l|}
$\begin{array}{l}\text { Resistance of managers to } \\
\text { changes }\end{array}$ & 1 & 2 & 3 & 4 & 5 & 6 & 7 \\
\hline
\end{tabular}

ENVIRONMENT RELATED BARRIERS

\begin{tabular}{|l|l|l|l|l|l|l|l|}
\hline $\begin{array}{l}\text { Insufficient support from } \\
\text { government }\end{array}$ & 1 & 2 & 3 & 4 & 5 & 6 & 7 \\
\hline $\begin{array}{l}\text { Inadequate regional } \\
\text { infrastructure }\end{array}$ & 1 & 2 & 3 & 4 & 5 & 6 & 7
\end{tabular}

infrastructure

INFORMATION RELATED BARRIERS

\begin{tabular}{|l|l|l|l|l|l|l|l|} 
Lack of opportunities for & & & & & & &
\end{tabular}

\begin{tabular}{|l|l|l|l|l|l|l|l|} 
innovation related & 1 & 2 & 3 & 4 & 5 & 6 & 7
\end{tabular}

cooperation

\begin{tabular}{|l|l|l|l|l|l|l|l|} 
Lack of market information & 1 & 2 & 3 & 4 & 5 & 6 & 7
\end{tabular}

\begin{tabular}{|l|l|l|l|l|l|l|l|l} 
Lack of information about & 1 & 2 & 3 & 4 & 5 & 6 & 7
\end{tabular}

In addition to the perception of different barriers to innovative projects, respondents were asked whether according to their perception, their company introduced any innovation in the past two years. In this way, respondents expressed their perception of the innovativeness of their company. Of the total number of respondents, $70 \%$ answered this question affirmatively.

Obtained data were processed using a statistical analysis program Statistica, version 13.0 Software.dell.com. Based on individual responses, mean values for individual independent variables were calculated: aspects of perception of risks as barriers to innovation projects, perception of financial problems as barriers to innovation projects, perception of employee structure as barriers to innovation projects, perception of activities and attitudes of management as barriers to innovation projects, perception of situation in environmental barriers to innovation projects and the perception of lack of information as barriers to innovation projects. The educational level of the respondents, respondents' perception of the company's innovativeness and the ownership structure of the company were the independent variables in this survey. Analysis of differences in the degree of perception of individual barriers was made on the basis of differences in the mean values of the perceptions and obtained variances.

\section{Research results}

Research results were systematized by groups of barriers to initiating and implementing innovative projects in the companies in Serbia. The perception of different risks as the barriers to the initiation and implementation of innovative projects by the employees, depending on the level of education of the respondent, company's innovativeness and the ownership structure of the company, is presented in Table 2.

TABLE II. - ASSESSMENT OF IMPORTANCE OF RISK RELATED BARRIERS FOR INNOVATIVE PROJECTS IN DEPENDENCE OF RESPONDENTS' EDUCATIONAL LEVEL, COMPANY'S INNOVATIVENESS, AND OWNERSHIP OF THE COMPANY

\begin{tabular}{lll}
\hline & $\begin{array}{l}\text { Increased } \\
\text { risk }\end{array}$ & $\begin{array}{l}\text { Turbulent } \\
\text { economic } \\
\text { situation }\end{array}$ \\
\hline EDUCATIONAL LEVEL & \\
$\begin{array}{l}\text { High school } \\
\text { University }\end{array}$ & $4,94 \pm 1,83$ & $5,91 \pm 1,38$ \\
\hline INNOVATIVENESS & $4,52 \pm 1,99$ & $5,78 \pm 1,42$ \\
\hline Non innovative & & \\
companies & $5,62 \pm 1,57$ & $6,23 \pm 1,48$ \\
Innovative companies & $4,50 \pm 1,94$ & $5,76 \pm 1,36$ \\
\hline OWNERSHIP & & \\
\hline Public companies & $3,19 \pm 1,77$ & $5,38 \pm 1,57$ \\
Domestic companies & $6,12 \pm 0,59$ & $6,54 \pm 1,20$ \\
Multinationals & $5,66 \pm 1,35$ & $6,09 \pm 1,12$ \\
\hline
\end{tabular}

Respondents evaluated increased risk and turbulent economic situation as aspects of risk barriers and, without exception, declared that the 
turbulent economic situation poses a higher risk in relation to the increased risk that the act of introduction of new products or services itself. Differences in the perception of the significance of this group of barriers were not found among the respondents of different degrees of education. However, both risk barriers were ranked higher by the respondents that perceived their company as noninnovative in comparison to the respondents that perceived that their company is innovative. This observation points out the possibility that due to the perception of high risk and the tendency to avoid risks by the employees, some companies do not decide to implement innovative projects.

The perception of increased risk due to the introduction of innovations is at the lowest level among the employees from the public companies, which is probably due to the fact that these companies in the Serbian market are not in the open market but rather have some kind of monopoly. Both aspects of risk as a barrier to the implementation of innovation projects are at the highest level perceived by the employees in the domestic companies, while in the subsidiaries of the multinational companies riskrelated barriers are ranked lower. This observation indicates that domestic enterprises are likely to have less developed risk management mechanisms and thus, the employees perceive risks as higher barriers to innovation.

In the case of barriers related to the financial aspects of the innovation process (Table 3), there are also no differences among respondents in dependence on their level of education. In the case when the company is perceived as innovative, this group of barriers is, as a rule, ranked lower than in the companies perceived as non-innovative.

TABLE III. - ASSESSMENT OF IMPORTANCE OF FINANCE RELATED BARRIERS FOR INNOVATIVE PROJECTS IN DEPENDENCE OF RESPONDENTS' EDUCATIONAL LEVEL, COMPANY'S INNOVATIVENESS, AND OWNERSHIP OF THE COMPANY

\begin{tabular}{|c|c|c|c|}
\hline & High costs & $\begin{array}{l}\text { Difficulties in } \\
\text { expenditures } \\
\text { management }\end{array}$ & $\begin{array}{c}\text { Difficulties } \\
\text { in access } \\
\text { to } \\
\text { financing } \\
\text { sources } \\
\end{array}$ \\
\hline \multicolumn{4}{|c|}{ EDUCATIONAL LEVEL } \\
\hline High school & $5,52 \pm 1,47$ & $5,33 \pm 1,57$ & $5,62 \pm 1,62$ \\
\hline University & $5,42 \pm 1,57$ & $5,18 \pm 1,60$ & $5,34 \pm 1,54$ \\
\hline \multicolumn{4}{|c|}{ INNOVATIVENESS } \\
\hline $\begin{array}{l}\text { Non innovative } \\
\text { companies }\end{array}$ & $5,85 \pm 1,17$ & $5,72 \pm 1,39$ & $6,38 \pm 1,33$ \\
\hline $\begin{array}{l}\text { Innovative } \\
\text { companies }\end{array}$ & $5,39 \pm 1,56$ & $5,17 \pm 1,59$ & $5,28 \pm 1,53$ \\
\hline \multicolumn{4}{|l|}{ OWNERSHIP } \\
\hline $\begin{array}{l}\text { Public } \\
\text { companies }\end{array}$ & $4,73 \pm 1,74$ & $4,36 \pm 1,59$ & $4,66 \pm 1,66$ \\
\hline $\begin{array}{l}\text { Domestic } \\
\text { companies }\end{array}$ & $6,14 \pm 0,61$ & $6,22 \pm 0,62$ & $6,88 \pm 0,59$ \\
\hline Multinationals & $5,96 \pm 1,19$ & $5,83 \pm 1,36$ & $5,82 \pm 1,26$ \\
\hline
\end{tabular}

This finding indicates that the causes of the absence of initiation and implementation of innovative projects can also be of a financial nature.
When it comes to the ownership structure of the company, the differences between the three observed groups of companies are striking. Finance related barriers are ranked at the lowest level in public enterprises in which the funds for innovation are provided from the state budget, while in the companies with domestic ownership financial barriers are ranked at the highest level indicating that for these group of companies the access to the sources for financing of innovative projects is a problem.

In the case of employee-related barriers to the implementation of innovation projects (Table 4), there is also no difference between respondents in dependence on education level.

TABLE IV. - ASSESSMENT OF IMPORTANCE OF EMPLOYEES' RELATED BARRIERS FOR INNOVATIVE PROJECTS IN DEPENDENCE OF RESPONDENTS' EDUCATIONAL LEVEL, COMPANY'S INNOVATIVENESS, AND OWNERSHIP OF THE COMPANY

\begin{tabular}{|c|c|c|c|c|}
\hline & $\begin{array}{l}\text { The } \\
\text { resistance } \\
\text { of the } \\
\text { employees } \\
\text { to } \\
\text { changes }\end{array}$ & $\begin{array}{c}\text { Lack of } \\
\text { qualified } \\
\text { workforce }\end{array}$ & $\begin{array}{c}\text { The } \\
\text { problem } \\
\text { of } \\
\text { retention } \\
\text { of } \\
\text { qualified } \\
\text { workforce } \\
\text { in the } \\
\text { company }\end{array}$ & $\begin{array}{c}\text { Lack of } \\
\text { training } \\
\text { for } \\
\text { employees }\end{array}$ \\
\hline \multicolumn{5}{|c|}{ EDUCATIONAL LEVEL } \\
\hline $\begin{array}{l}\text { High } \\
\text { school }\end{array}$ & $\begin{array}{l}4,64 \\
\pm 1,73\end{array}$ & $4,43 \pm 1,92$ & $4,60 \pm 1,82$ & $4,57 \pm 1,82$ \\
\hline University & $\begin{array}{l}4,64 \\
\pm 1,83\end{array}$ & $4,78 \pm 1,80$ & $4,81 \pm 1,69$ & $4,70 \pm 1,78$ \\
\hline \multicolumn{5}{|c|}{ INNOVATIVENESS } \\
\hline $\begin{array}{l}\text { Non inno- } \\
\text { vative } \\
\text { companes }\end{array}$ & $4,5 \pm 1,87$ & $3,30 \pm 1,81$ & $3,64 \pm 2,06$ & $3,80 \pm 1,97$ \\
\hline $\begin{array}{l}\text { Innovative } \\
\text { companies }\end{array}$ & $\begin{array}{c}4,71 \\
\pm 1,74 \\
\end{array}$ & $4,93 \pm 1,93$ & $4,96 \pm 1,55$ & $4,85 \pm 1,70$ \\
\hline \multicolumn{5}{|c|}{ OWNERSHIP } \\
\hline $\begin{array}{l}\text { Public } \\
\text { companies }\end{array}$ & $3,88 \pm 1,84$ & $4,68 \pm 1,87$ & $4,91 \pm 1,68$ & $4,69 \pm 1,84$ \\
\hline $\begin{array}{l}\text { Domestic } \\
\text { companies }\end{array}$ & $3,74 \pm 1,71$ & $2,26 \pm 0,96$ & $2,26 \pm 0,85$ & $2,56 \pm 0,97$ \\
\hline $\begin{array}{l}\text { Multinatio- } \\
\text { Nals }\end{array}$ & $5,61 \pm 1,18$ & $5,26 \pm 1,46$ & $5,24 \pm 1,39$ & $5,23 \pm 1,48$ \\
\hline
\end{tabular}

In the case of company innovativeness, there are differences in ranking deficiencies and the inability to retain qualified workforce and training shortages with employees assessing their company as innovative ranking these barriers higher in comparison to the employees that consider that their company is noninnovative.

Interestingly, employee-related barriers are generally ranked higher by the employees from subsidiaries of multinational companies, while the employees from the companies with domestic ownership, these barriers are ranked at the lowest level. It is important to point out that employeesrelated barriers are, as a rule, rated lower in comparison to the risk- and finance-related barriers. 
Perceptions of the barriers related to the company's management structure (Table 5) do not differ for respondents of different education level.

Dependence of perception of company's innovativeness by the respondent major difference was also not noticed. This group of barriers is ranked at the lowest level by the respondents from companies with domestic ownership. This observation points out that among the owners of these companies most probably there are initiatives for implementation of innovative projects. On the other hand, in multinationals' subsidiaries, these barriers are rated at a higher level suggesting that managers at the local level probably have no initiative (possibly no authority) to launch innovation projects.

TABLE V. - ASSESSMENT OF IMPORTANCE OF MANAGEMENT RELATED BARRIERS FOR INNOVATIVE PROJECTS IN DEPENDENCE OF RESPONDENTS' EDUCATIONAL LEVEL, COMPANY'S INNOVATIVENESS, AND OWNERSHIP OF THE COMPANY

\begin{tabular}{lcc}
\hline & $\begin{array}{c}\text { Lack of } \\
\text { systematic } \\
\text { actions in the } \\
\text { company }\end{array}$ & $\begin{array}{c}\text { The } \\
\text { resistance of } \\
\text { management } \\
\text { to changes }\end{array}$ \\
\hline EDUCATIONAL LEVEL & \\
\hline High school & $4,80 \pm 1,54$ & $4,57 \pm 1,63$ \\
University & $4,71 \pm 1,76$ & $4,37 \pm 1,80$ \\
\hline INNOVATIVENESS & & \\
\hline Non innovative & $4,22 \pm 1,50$ & $4,11 \pm 1,90$ \\
companies & $4,90 \pm 1,50$ & $4,58 \pm 1,66$ \\
\hline Innovative companies & & \\
\hline OWNERSHIP & $4,61 \pm 1,71$ & $3,99 \pm 1,86$ \\
Dublic companies & $3,36 \pm 1,01$ & $3,30 \pm 1,69$ \\
Multinationals & $5,27 \pm 1,25$ & $5,21 \pm 1,25$ \\
\hline
\end{tabular}

Barriers related to external factors (Table 6) are also perceived at the highest level by the employees from domestic companies, while in the subsidiaries of multinational companies, employees experience these barriers at the lowest level.

TABLE VI. - ASSESSMENT OF IMPORTANCE OF EXTERNAL FACTORS RELATED BARRIERS FOR INNOVATIVE PROJECTS IN DEPENDENCE OF RESPONDENTS' EDUCATIONAL LEVEL, COMPANY'S INNOVATIVENESS, AND OWNERSHIP OF THE COMPANY

\begin{tabular}{lcc}
\hline & $\begin{array}{c}\text { Insufficient } \\
\text { support from } \\
\text { the } \\
\text { government }\end{array}$ & $\begin{array}{c}\text { Inadequate } \\
\text { regional } \\
\text { infrastructure }\end{array}$ \\
\hline EDUCATIONAL LEVEL & & \\
\hline $\begin{array}{l}\text { High school } \\
\text { University }\end{array}$ & $5,09 \pm 1,51$ & $4,75 \pm 1,68$ \\
\hline INNOVATIVENESS & $4,92 \pm 1,68$ & $4,93 \pm 1,58$ \\
\hline $\begin{array}{l}\text { Non innovative } \\
\text { companies } \\
\text { Innovative companies }\end{array}$ & $4,70 \pm 1,56$ & $4,53 \pm 1,52$ \\
\hline OWNERSHIP & $5,08 \pm 1,08$ & $4,97 \pm 1,64$ \\
\hline Public companies & $4,61 \pm 1,84$ & $4,02 \pm 1,72$ \\
Domestic companies & $3,98 \pm 1,13$ & $4,14 \pm 0,83$ \\
Multinationals & $5,64 \pm 1,21$ & $5,83 \pm 1,16$ \\
\hline
\end{tabular}

In respect to respondents" education level and their perception of the company's innovativeness in the case of barriers related to external factors, there are no remarkable differences.

The lack of different information as a barrier to the implementation of innovation projects (Table 7) is ranked at the highest by the employees in subsidiaries of multinational companies, while this group of barriers is perceived at the lowest level by the employees form the public companies.

In the case of information-related barriers, there are also no remarkable differences in respect to respondents" education level and their perception of company's innovativeness.

TABLE VII. - ASSESSMENT OF IMPORTANCE OF INFORMATION RELATED BARRIERS FOR INNOVATIVE PROJECTS IN DEPENDENCE OF RESPONDENTS' EDUCATIONAL LEVEL, COMPANY'S INNOVATIVENESS, AND OWNERSHIP OF THE COMPANY

\begin{tabular}{|c|c|c|c|}
\hline & $\begin{array}{c}\text { Lack of } \\
\text { market } \\
\text { Information }\end{array}$ & $\begin{array}{c}\text { Lack of } \\
\text { opportunities } \\
\text { for } \\
\text { Innovation } \\
\text { related } \\
\text { cooperation }\end{array}$ & $\begin{array}{c}\text { Lack of } \\
\text { informa- } \\
\text { tion about } \\
\text { new } \\
\text { techno- } \\
\text { logies }\end{array}$ \\
\hline \multicolumn{4}{|c|}{ EDUCATIONAL LEVEL } \\
\hline High school & $4.63 \pm 1,64$ & $4,62 \pm 1,70$ & $4,60 \pm 1,77$ \\
\hline University & $4,61 \pm 1,76$ & $4,62 \pm 1,77$ & $4.55 \pm 1,91$ \\
\hline \multicolumn{4}{|c|}{ INNOVATIVENESS } \\
\hline $\begin{array}{l}\text { Non innovati- } \\
\text { ve companies }\end{array}$ & $4,34 \pm 1,56$ & $4,42 \pm 1,51$ & $4,64 \pm 1,52$ \\
\hline $\begin{array}{l}\text { Innovative } \\
\text { companies }\end{array}$ & $4,71 \pm 1,74$ & $4,70 \pm 1,78$ & $4,59 \pm 1,92$ \\
\hline \multicolumn{4}{|l|}{ OWNERSHIP } \\
\hline $\begin{array}{l}\text { Public compa- } \\
\text { Nies }\end{array}$ & $3,84 \pm 1,75$ & $3,72 \pm 1,76$ & $3,84 \pm 1,91$ \\
\hline $\begin{array}{l}\text { Domestic } \\
\text { companies }\end{array}$ & $3,94 \pm 1,11$ & $4,12 \pm 1,10$ & $4,08 \pm 0,88$ \\
\hline Multinationals & $5,54 \pm 1,38$ & $5,57 \pm 1,37$ & $5,36 \pm 1,72$ \\
\hline
\end{tabular}

\section{DISCUSSION AND CONCLUSION}

The average values of the perceptions of barriers to the implementation of innovation projects by the employees in the companies in Serbia, depending on the sources of barriers, but also from the perception of innovation and ownership structure of the company on a scale of 1 (negligible barriers) to 7 (very high barriers) range from 2.26 to 6.88 .

The highest average values of the perception of the barriers to innovation projects were recorded in the case of barriers related to financial aspects of innovation projects implementation, i.e. the costs of innovating, in the case of the companies with domestic ownership.

The lowest average perception of barriers is also recorded among the employees in the companies with domestic ownership in the case of employee-related barriers but in the case of management-related barriers. Such findings indicate that in the companies with domestic ownership there is a tendency of attribution of barriers to innovation projects to the 
financial problems, while the responsibilities of managers and employees themselves as the drivers of the innovation process are neglected.

In respect to the stated hypotheses of the present research, based on presented results considerations related to the bases for the hypotheses acceptance or rejecting can be carried out. On the basis of obtained results, the hypothesis that the perception of the barrier to the implementation of innovative projects in companies in Serbia by employees depends on the level of their education $\left(\mathrm{H}_{01}\right)$ cannot be supported since there are no notable differences among the mean values of perception of all observed barriers between respondents with high school and with university education.

The hypothesis that the perception of barriers to the implementation of innovation projects in companies in Serbia by the employees depends on employees' perception of their company's innovativeness $\left(\mathrm{H}_{02}\right)$ can, on the basis of presented results, be supported with the exception of the information-related barriers. The hypothesis that the perception of the barriers to the implementation of innovative projects is higher in the case of employees who perceive their company as non-innovative $\left(\mathrm{H}_{02-1}\right)$ can be supported in the cases of risk- and financerelated barriers. However, in the case of employeesmanagement- and environment-related barriers findings opposing this hypothesis were obtained: employees perceiving their company as innovative perceive these barriers at a higher level than those who do not perceive their company as innovative.

The hypothesis that the perception of the barriers to the implementation of innovative projects in companies in Serbia by the employees depends on the ownership structure of the company $\left(\mathrm{H}_{03}\right)$ can be, based on presented results, supported in the case of all observed barriers.

Hypothesis $\left(\mathrm{H}_{03-1}\right)$ stating that the employees in public companies in Serbia have the lowest perceptions of barriers to the implementation of innovative projects can be supported in the case of risks- finance- and information-related barriers. In the case of the environment- and human factors (employees and managers) related barriers the perception of barriers in public enterprises is lower than in subsidiaries of multinational companies, while in the companies with domestic ownership the perception of these barriers by the employees is even lower.

Hypothesis $\left(\mathrm{H}_{03-2}\right)$ stating that the employees in the subsidiaries of multinational companies in Serbia have the highest perceptions of barriers to the implementation of innovation projects cab, on the basis of obtained results be supported in the case of information-, environment-, employees- and management- related barriers, while in the case of risk- and finance-related barriers perception of barriers in these companies is at lower level.
The perception of the barriers to innovation and the implementation of innovation projects in Serbia, with rare exceptions, is at a relatively high level, imposing certainly the limitation to the implementation of innovation projects in Serbia. The perception of the barriers to the innovative projects does not depend on the employee's education level, but it is largely dependent on employee perception about the innovativeness of the company and differs among companies in dependence on the ownership structure.

Consequently, activities aimed at overcoming of barriers to innovation projects should be planned and implemented. The perception of the barriers by the employees in each specific case should be considered. Overcoming the perception of the barriers to innovation projects among employees should be fostered in order to empower the successfully wider implementation of innovation projects in the companies in Serbia.

\section{REFERENCES}

[1] F. P. Drucker, Inovacije i preduzetništvo - praksa i principi, Privredni pregled, Beograd, 1991, pp 56.

[2] D. M. Mumford, and B. S. Gustafson, "Creativity syndrome: integration, application, and innovation," in Psychological Bulletin, vol. 103(1), 1988, pp. 27-43.

[3] T.M. Amabile, "The social psychology of creativity: A componential conceptualization," in Journal of personality and social psychology, 45(2), 357, 1983

[4] T. M. Amabile, R. Conti, R., H. Coon, J. Lazenby, and M. Herron, "Assessing the Work Environment for Creativity," Academy of Management Journal, vol. 39(5), 1996, pp.11541184.

[5] K. M. Hingley, A. Lindgreen, and B. M., Beverland, (2010). "Barriers to network innovation in UK ethnic fresh produce supply," Entrepreneurship and Regional Development, vol. 22(1), pp.77-96 http://www.icip-serbia.org/, retrieved 8.10.2015.

[6] T. H. Wagner, C. S. Morton, R. A. Dainty, and D. N. Burns, "Path dependent constraints on innovation programmes in production and operations management," International Journal of Production Research, vol. 49(11), pp. 3069-3085, 2011

[7] G. Marin, A. Marzucchi, and R. Zoboli, "SMEs and barriers to Eco-innovation in the EU: exploring different firm profiles," Journal of Evolutionary Economics, vol.25(3), 2015, pp. 671-705.

[8] J. C. Jabbour, L. B. A. de Sousa Jabbour, K. Govindan, P. T. De Freitas, F. D. Soubihia, D. Kannan, and H. Latan. "Barriers to the adoption of green operational practices at Brazilian companies: effects on green and operational performance," International journal of production research, vol. 54(10), 2016, pp. 3042-3058.

[9] P. Larsen, and A. Lewis, "How award-winning SMEs manage the barriers to innovation," Creativity and innovation management, vol. 16(2), 2007, pp. 142-151.

[10] G. Smith, and J. Sandberg, "Barriers to innovating with open government data: Exploring experiences across service phases and user types." Information Polity, (Preprint), 2018, pp. 117.

[11] M. Bešlin, "Serbia and modernization from 1968 to 1972", Politikon, vol. (11), 2015, pp. L22-39.

[12] J. S. Petrović, and O. S. Marković-Savić, "On Social Inequalities on the Pages of the Sociological Review in the Period of Self-Management Socialism," Sociološki pregled [Sociological Review], vol. LVII, 2018 (1), 2018, pp. 181215 . 
[13] T. Ratković, "The expatriates in multinational companies: A trend in Serbia," Megatrend revija, vol. 11 (1), 2014, pp. 2232401 .

[14] L. Nikolić, M.. Kovačević, "The impact of privatization: Empirical analysis and results in Serbian industry," Industrija, vol. 42 (1), 2014, pp. 63-86.

[15] B. Leković, "Entrepreneurs perception of barriers for development of innovation: Analysis of data from northern Bačka county," Megatrend revija, vol. 10(4), 2013, pp. 95114.

[16] V. Kartal, "Stanje i barijere tehnološkim inovacijama u preduzeću Beogradske elektrane," Master rad. Fakultet za projektni i inovacioni menadžment, Beograd, 2015, pp.23-26.

[17] B. Stošić, Menadžment inovacija, Ekspertni sistemi, modeli i metodi, Beograd: FON, 2007.

[18] OECD, 2005, "The Measurement of Scientific and Technological Activities: Guidelines for Collecting and Interpreting Innovation Data: Oslo Manual, Third Edition" prepared by the Working Party of National Experts on Scientific and Technology Indicators, OECD, Paris, para. 146

[19] P. Jovanović, Lj. Tančić, Đ. Lajšić, and M. Vuković, Upravljanje inovacijama i projektni menadžment, Beograd: Visoka škola strukovnih studija za projektni menadžment, 2012

[20] D. Ristić, Upravljanje razvojem, Sremski Karlovci: Cekom books, 2008.

[21] M. Levi - Jakšić, Menadžment inovacija i tehnološkog razvoja, Beograd: FON, 2007.

[22] L. L. Cummings, and J. M. O'Connell, "Organizational Innovation," Journal of Business Research vol. 6, 1978, pp. 33-50.

[23] W. R. Woodman, E. J. Sawyer, and W. R. Griffin, "Toward a Theory of Organizational Creativity," Academy of Management Review, vol. 18(2), 1993, pp. 293-321.

[24] L. Gumusluog, and A. Ilsev, "Transformational Leadership and Organizational Innovation: The Roles of Internal and External Support for Innovation," Product Innovation Management, vol. 26, 2009, pp. 264-277.

[25] R. G. Oldham, and A. Cummings, "Employee Creativity: Personal and Contextual Factors at Work," Academy of Management Journal, vol. 39(3), 1996, pp. 607-634.

[26] P. Tierney, M. S. Farmer, and B. G. Graen, "An Examination of Leadership and Employee Creativity: The Relevance of Traits and Relationships," Personnel Psychology, vol. 52, 1999, pp. 591-620.

[27] M. T. Amabile, A. E. Schatzel, B. G. Moneta, and J. S. Kramer, "Leader Behaviors and the Work Environment for Creativity: Perceived Leader Support," Leadership Quarterly, vol. 15(1), 2004, pp. 5-32.

[28] G. S. Scott, and A. R. Bruce, "Determinants of Innovative Behavior: A Path Model of Individual Innovation in the Workplace," Academy of Management Journal, vol. 37(3), 1994, pp. 580-607.

[29] I. D. Jung, C. Chow, and A. Wu, "The Role of Transformational Leadership in Enhancing Organizational Innovation: Hypotheses and Some Preliminary Findings," Leadership Quarterly, vol. 14, 2003, pp. 525-544.

[30] Lj. Miletić, S. Karović, i Ž. Sajfert, Liderstvo u projektnom menadžmentu-Teorija i praksa, Zrenjanin: Tehnički fakultet "Mihajlo Pupin", 2016

[31] A. Oke, "Barriers to innovation management in service companies," Journal of Change Management, vol. 4(1), 2004, pp. 31-44.

[32] A. P. Vermeulen, "Uncovering barriers to complex incremental product innovation in small and medium-sized financial services firms," Journal of Small Business Management, vol. 43(4), 2005, pp. 432-452.

[33] V. O. Valieva, "Personnel Resources for Innovation Companies: Values and Goals," Problems of Economic Transition, vol. 56(6), 2013, pp. 80-88.
[34] P. M. Perez, M. A. Sanchez, and P. M. De Luis Carnicer, "Top Manager and Institutional Effects on the Adoption of Innovations: The Case of Teleworking 1," Prometheus, vol. 21(1), 2003, pp. 58-73.

[35] V. Souitaris, "Strategic influences of technological innovation in Greece,” British Journal of Management, vol. 12(2), 2001, pp. 131-147. 